\title{
Detection of Ochratoxin A From Poultry Feed Using High Pressure Liquid Chromatography.
}

\author{
Adeniran L.A ${ }^{1 *}$, Makun H.A ${ }^{2}$, Mohammad H.A ${ }^{2}$ and Ajagbonna O.P \\ ${ }^{1}$ Department of Physiology and Biochemistry, Faculty of Veterinary Medicine, \\ University of Abuja, Nigeria. \\ ${ }^{2}$ Department of Biochemistry, Federal University of Technology, Minna, Nigeria. \\ ${ }^{3}$ Department of Pharmacology and Toxicology, Faculty of Veterinary Medicine, \\ University of Abuja, Nigeria
}

Accepted January, 2019 and Published February, 2019

\begin{abstract}
One hundred poultry feed samples comprising of commercially produced poultry feed (48) and poultry feed compounded by farmers (privately milled) (52) were collected from farms located in Minna and analysed for Ochratoxin A (OTA), a member of group 2 possible carcinogen by High Pressure Liquid Chromatographic (HPLC) method. Thirty seven percent of the commercial poultry feeds were contaminated with OTA at a range of $0-236.73 \mu \mathrm{g} / \mathrm{kg}$ while hundred percent of privately made feed were contaminated with OTA at a range of 22.76-226.51 $\mu \mathrm{g} / \mathrm{kg}$. The finding of this investigation showed that $71 \%(71 / 100)$ of the sampled poultry feed has OTA concentrations which was far in excess of the maximum permissible limit of $5 \mu \mathrm{g} / \mathrm{kg}$ (the European Union Standard). This is of serious health concern to the birds and humans that consume the poultry products.
\end{abstract}

Keywords: Ochratoxin A, Poultry feed, Chromatography, Mycotoxin.

*Corresponding author:

Email: lateef.adeniran@uniabuja.edu.ng

Tel: $234-8155169822$ 


\section{INTRODUCTION}

Fungal contamination of food and feed, with its attendant mycotoxin production, is a significant problem globally. Mycotoxins are secondary metabolites that have adverse effects on human, animals and crops, resulting in diseases and economic losses. Ochratoxin A(OTA) is one of the most important mycotoxins, together with aflatoxins, fumonisins, trichothecenes and zearalenone [1-3]. It is a nephrotoxic and nephrocarcinogenic mycotoxin produced by Penicillium verrucosum in temperate regions, and Aspergillus species, such as $A$. ochraceus, $A$. melleus, $A$. carbonarius, $A$. niger, in warmer and tropical parts of the world [4-6]. The carcinogenicity of OTA has been evaluated by International Agency for Research on Cancer (IARC) [7] and classified it as a possible Group 2B human carcinogen. OTA producers present in raw materials used in poultry feed production and cereals are considered the main source of the intake of OTA metabolites [8]. Wheat, maize and sorghum have been reported as substrate for fungal growth and OTA production [9]. Sometimes there is cocontamination with aflatoxin or other mycotoxins [9-10].

Poultry, like other monogastric animals, derives energy mainly from carbohydrates and fat since fibre containing cellulose cannot be digested and utilized [10]. Components of poultry feed are carbohydrates, lipids, protein, vitamins, water, probiotics and other supplements. Poultry feed are produced by manufacturers commercially for sale to farmers having large poultry farms or small poultry holdings $[8,9]$. Farmers may also provide feed for their birds by formulating and compounding their own. Depending on cost, availability of raw materials and age or type of poultry, some of the following products are also frequently used in the production of poultry feed; bye- products of cereal grain processed for human use, animal waste, groundnut cake, fishmeal, waste oil from restaurants, yeasts alfalfa meal [10]. In Nigeria, though several investigators have reported the natural occurrence of OTA in poultry feed and ingredients [11-13], [8], [14], information on OTA in processed products like poultry feed is scarce except few work [14-15]. The present study was therefore undertaken to determine the level of OTA in poultry feed in Minna, North-central Nigeria.

\section{MATERIAL AND METHODS}

\section{Sampling}

One hundred poultry feed samples, from twenty one poultry farms in Minna, Niger state, were randomly collected daily in the month of February and March.

Fifty two samples from privately milled poultry feed were collected from six different farms and forty eight samples from six commercial poultry feed brands were also taken from fifteen farms using commercial feed. These samples were taken before the feed were served to birds.' The samples were labelled based on the manufacturer as commercial feed or privately milled feed. The commercial feed were labelled according to their different brands as V-Feed, $F$ Feed, T-Feeds, R-Feed, L-Feeds and the private feed labelled with letters A, B, C, D, E, \& F. About $200 \mathrm{~g}$ of each of the feeds was taken and packaged in a well-labelled paper bags and immediately taken to the laboratory for fungal isolation, identification and mycotoxin analysis. 


\section{Extraction of Ochratoxin A}

Ochratoxin A was extracted using AOAC standard method [16]. Briefly, $50 \mathrm{~g}$ of pulverized samples were weighed into $500 \mathrm{ml}$ Erlenmeyer flask. $25 \mathrm{ml} \mathrm{1M-phosphoric} \mathrm{acid}$ and $250 \mathrm{ml}$ of methylene chloride were added. The flask was shaken for 30 minutes using a shaker and the content filtered under pressure on Buchner funnel fitted with $18 \mathrm{~cm}$ circle rapid filter paper. About $200 \mathrm{ml}$ of the filtrate was collected. From this, $50 \mathrm{ml}$ aliquots were placed in separate $100 \mathrm{ml}$ Erlenmeyer flasks with glass stoppers and subjected to specific clean-up for OTA assay as follows: Bicarbonate solution $(70 \mathrm{ml})$ was added and shaken. After phase separation, the lower methylene chloride layer was drained into a $250 \mathrm{ml}$ separatory funnel with addition of $35 \mathrm{ml}$ sodium bicarbonate solution. The lower methylene chloride layer was discarded and the aqueous layer acidified to $\mathrm{pH} 3.5$ with sulphuric acid. The acidified layer was transferred into a second separatory funnel and OTA further extracted into $50 \mathrm{ml}$ of methylene chloride which was drained through a sodium sulphate into a beaker. After two rinses with $50 \mathrm{ml}$ each of methylene chloride, the pooled extract was evaporated to dryness and transferred into $4 \mathrm{ml}$ amber vial sample bottle, and stored at $-20^{\circ} \mathrm{C}$ in the deep freezer until used for analysis. The dry film was reconstituted with $200 \mu \mathrm{L}$ mobile phase (Acetonitrile: water: acetic acid (50:48:2) for HPLC analysis.

\section{High Pressure Liquid Chromatography}

OTA was quantified on Cecil 1100 series HPLC with UV detection as described [17] at wavelength of $254 \mathrm{~nm}$. The altraspher ODS column, $4.6 \mathrm{~mm} \times 25 \mathrm{~cm}$ was used at ambient temperature of $25^{\circ} \mathrm{C}$. Acetonitrile: water and acetic acid in ratio 50:48:2 respectively was used as mobile phase at flow rate $1 \mathrm{ml} / \mathrm{min}$. The injection volume was $60 \mu \mathrm{l}$. Calibration curve with a correlation factor of 0.925 was determined using series of dilutions containing $0.023 \mu \mathrm{g} / \mathrm{ml}, 0.018 \mu \mathrm{g} / \mathrm{ml}, 0.014 \mu \mathrm{g} / \mathrm{ml}, 0.009$ $\mu \mathrm{g} / \mathrm{ml}$ and $0.004 \mu \mathrm{g} / \mathrm{ml}$. The retention time for OTA was 1.11 minutes while the detection limit of the machine with regards to the toxin was $0.001 \mu \mathrm{g} .10 \mu \mathrm{g} / \mathrm{ml}$ of OTA was spiked in three samples of each food commodity and recovery rates determined. The observed recoveries indicate that the sensitivity and reliability of the methods employed were sufficient for evaluation ofOTA in animal feed.

\section{Statistical Analysis}

All data were subjected to statistical analysis, frequency distribution and ANOVA using SPSS (version 16.0) software. The statistical level of significance was fixed at $\mathrm{P}<0.05$.

\section{RESULT}

The Table 1 showed that $100 \%(52 / 52)$ of privately milled poultry feed samples were contaminated at a concentration that ranges between 22.76 to $226.51 \mu \mathrm{g} / \mathrm{kg}$ while $37 \%$ $(19 / 48)$ of commercial feed samples were contaminated at a range of 0 to 236.73 . The mean concentration of OTA in the feed sample is $65.29 \pm 5.43$ and $44.42 \pm 10.15$ for privately milled and commercial poultry feeds respectively. Tables 2 and 3 show the range of concentration of OTA in the different commercial feed samples. It should be noted that only samples from commercial feed had $70 \%$ contamination. Table 4 show the number and percentage of samples found at different ranges of OTA concentration. The highest samples contaminated $29 / 100$ were found at 0 $\mu / \mathrm{kg}$ concentration followed by $25 / 100$ samples found at 50 to $100 \mu / \mathrm{kg}$. The HPLC 
recovery rate of 91 to $93 \%$ was recorded for both private and commercial feeds respectively as shown in Table 5.

\section{DISCUSSION}

Attempt towards documentation of mycotoxin contaminating animal feeds has been ongoing worldwide in order to be able to mitigate against the attendant effect of mycotoxicosis in animals [13], [14].

Table 1 summarises the incidence and concentration of OTA in commercial and privately milled poultry feed. The concentration reported were adjusted based on recovery rates obtained. This survey showed that OTA are contaminant of $71 \%$ of the poultry feed studied.

This result is similar to what was obtained in Kuwait where [18] reported $71.4 \%$ contamination in poultry feed. Though lower than $94 \%$ contamination of poultry feed recorded in Venezuela [19] but higher than $37.5-50 \%$ contamination of poultry reported in Spain [20].

The level of contamination of OTA in commercial feed sample is $37 \%$ while it is $100 \%$ in privately milled poultry feed. It should be noted that modern feed processing methods such as is employed by most commercial feed millers helps to remove part of the seed containing mycotoxin which may result in lower OTA prevalence [14]. The composition on the feed and the grade of the feed ingredient may also be responsible for the lower OTA prevalence found in commercial feed compared to the privately owned poultry feed. Most of the commercial feed mills use high grade grains, groundnut cake, soybeans, which were usually subjected to mycotoxin assay before they are used to compound feed. It was noted that commercial feed producers have a mechanism that prevent feed glut in the market which actually prevent retailers and whole sellers from storing or hoarding feed. This prevents unnecessary storage of feed which makes feed a good substrate for fungal growth and subsequent mycotoxin production. Since whole seller and retailers alike do not have conditioned ware house that can prevent fungal growth and mycotoxin production, many commercial feed producers also add toxin binders to the feed.

Hundred percent of privately milled poultry feed contain OTA at different concentrations.

This is attributable to the fact that most of the farms use cheap, low quality cereals and other feed ingredients. Most of their ingredients are sourced from the market, field or damaged, poorly stored or mouldy cereals [20]. This is done for economic reasons, in other to maximise profit from poultry production. Different investigators have reported different OTA level of contamination in maize and groundnut samples [8-9], [21].

The concentration of OTA ranges from 0 to $236.73 \mu \mathrm{g} / \mathrm{kg}$ in privately milled feed (Table 2 ). This is less than $320 \mu \mathrm{g} / \mathrm{kg}$ reported in poultry feed in Serbia [22], while higher than the value of $159.4 \mu \mathrm{g} / \mathrm{kg}$ documented in poultry feed in Iraq [23].

Poultry feed in Nigeria has been reported to be contaminated by ochratoxin A at range of 2.0$14.2 \mu \mathrm{g} / \mathrm{kg}$ [15], the value obtained in the present study is a cause for concern to the health of birds and the consumer of poultry products in Niger state. Apart from the nephrotoxic and the carcinogenic effects of OTA in birds, it also affects laying birds adversely causing a decrease of egg mean weight, congestion and haemorrhage, shell decalcification, egg size and shape [24]. In 
broilers, it causes decreased growth rate due to feed refusal by birds and decreased feed conversion [24-25] observed reduction in serum protein $G$ albumin. Due to the immunosuppressive effect of OTA, there is an increase in the outbreak of contagious diseases like salmonellosis and coccidiosis [26-30]. Our result showed that $71 \%$ of commercial feed and $37 \%$ of the privately milled poultry feed were contaminated by OTA at a level regarded as unsafe by the European Union EU limit of $5 \mu \mathrm{g} / \mathrm{kg}$ [31]. Such high levels of mycotoxin in poultry feed is as a result of many factors among which include the climate of Niger state which is warm (average annual temperature of $31.7 \%$ ) and humid (average annual humidity of $51.6 \%)$ These factors contribute to the proliferation of mycotoxigenic fungi [32].

Other factors include non-enforcement by regulatory bodies, general ignorance by farmers of the existence of mycotoxin. All these factors could be contributory to the high burden of OTA in this area as earlier reported [33]. The effects on human who take poultry product can be as a result of persistence of OTA in tissue [32], [34]. The attendant public health issue might be exacerbated in the study area because of the high OTA level. This is particularly so since food and egg producing birds were fed with feed that contained high level of OTA.

\section{Conclusion}

This study documents the levels of OTA in poultry feed, the observed high level in the study is of great public health importance and may be as a result of lack of enlightenment of farmers and total lack of enforcement of OTA acceptable daily intake on poultry feed. Good agricultural practices, public enlighten for farmers on the adverse effects of mycotoxins and enforcement of acceptable daily intake on feeds for birds will help to minimise the hazards of ochratoxicosis.

Table 1 : Occurrence of OTA in poultry feed samples

\begin{tabular}{llllll}
\hline $\begin{array}{l}\text { Type of } \\
\text { poultry feed } \\
\text { sampled }\end{array}$ & $\begin{array}{l}\text { Total number } \\
\text { of feed } \\
\text { samples }\end{array}$ & $\begin{array}{l}\text { Total number } \\
\text { contaminated } \\
\text { with OTA }\end{array}$ & $\begin{array}{l}\% \\
\text { contaminated } \\
\text { with OTA }\end{array}$ & $\begin{array}{l}\text { Range of OTA } \\
\text { concentration } \\
(\mu \mathrm{g} / \mathrm{kg})\end{array}$ & $\begin{array}{l}\text { Mean SD } \\
(\mu \mathrm{g} / \mathrm{kg})\end{array}$ \\
\hline $\begin{array}{l}\text { Private } \\
\text { milled }\end{array}$ & 52 & 52 & 100 & $22.76-226.51$ & $65.29 \pm 5.43$ \\
Commercial & 48 & 19 & 37 & $0-236.73$ & $44.42 \pm 10.15$ \\
\hline
\end{tabular}

Table 2: Occurrence and concentration $(\mu \mathrm{g} / \mathrm{kg})$ of OTA in samples of privately milled feeds.

\begin{tabular}{llcccccc}
\hline $\begin{array}{l}\text { Private } \\
\text { farms }\end{array}$ & \multicolumn{1}{c}{$\mathrm{A}$} & $\mathrm{B}$ & $\mathrm{C}$ & $\mathrm{D}$ & $\mathrm{E}$ & $\mathrm{F}$ & Total \\
\hline Occurrence & $4 / 4$ & $9 / 9$ & $9 / 9$ & $10 / 10$ & $10 / 10$ & $10 / 10$ & $52 / 52$ \\
Mean \pm SD & $118.6 \pm 10.6$ & $44.4 \pm 4.7$ & $61.7 \pm 7.0$ & $75.3 \pm 5.4$ & $35.5 \pm 1.7$ & $56.5 \pm 6.8$ & $5.3 \pm 5.4$ \\
Range & $95.2-142.5$ & $26.9-60.2$ & $22.8-226.3$ & $53.4-102$ & $27.4-43.3$ & $33.08-39.82$ & $22.8-226.5$ \\
\hline
\end{tabular}

Key: Letters A, B, C, D, E and F represent the Farms where samples were collected. 
Table 3: Occurrence and concentration $((\mu \mathrm{g} / \mathrm{kg})$ of OTA in feed samples of commercial feeds.

Commercial feeds $\mathrm{T}$

V

$\mathrm{L}$

$\mathbf{R}$

F Total

$\begin{array}{lllllll}\text { Occurrence } & 0 / 10 & 1 / 10 & 7 / 10 & 1 / 10 & 1 / 8 & 9 / 48\end{array}$

Mean \pm SD $\quad 0 \pm 0^{\text {acd }} 1.257 \pm 1.257^{\text {bcd }} \quad 60.84 \pm 24.1^{\text {abcd }} \quad 144.20 \pm 9.27^{\text {abcde }} 6.20 \pm 6.20^{\text {de }} 44.42 \pm 10$

$\begin{array}{llllll}\text { Range } & 0-0 & 0-12.5 & 0-209.2 & 64.96-236.7 & 0-236.73\end{array}$

- The concentration with superscript show that they are significant $\mathrm{P}<0.05$

Table 4. Range of OTA concentration and percentage of the analysed samples of OTA concentration in $(\mu \mathrm{g} / \mathrm{kg})$ in both privately milled and commercial feed samples

$\begin{array}{lll}\text { Range OTA } & \text { Number of samples } & \text { Percentage } \\ \text { concentration in } & & \\ \text { feed samples } & \end{array}$

\begin{tabular}{lllll}
$(\mu \mathrm{g} / \mathrm{kg})$ & Private & Commercial & Private & Commercial \\
0 & 0 & 29 & 0 & 50 \\
$<20$ & 0 & 1 & 0 & 2 \\
$20-50$ & 19 & 5 & 37 & 10 \\
$50-100$ & 20 & 5 & 39 & 10 \\
$100-200$ & 11 & 5 & 21 & 12 \\
$>200$ & 2 & 3 & 3.6 & 6 \\
\hline
\end{tabular}


Table 5: HPLC recovery of Ochratoxin A for commercial and privately milled poultry feed.

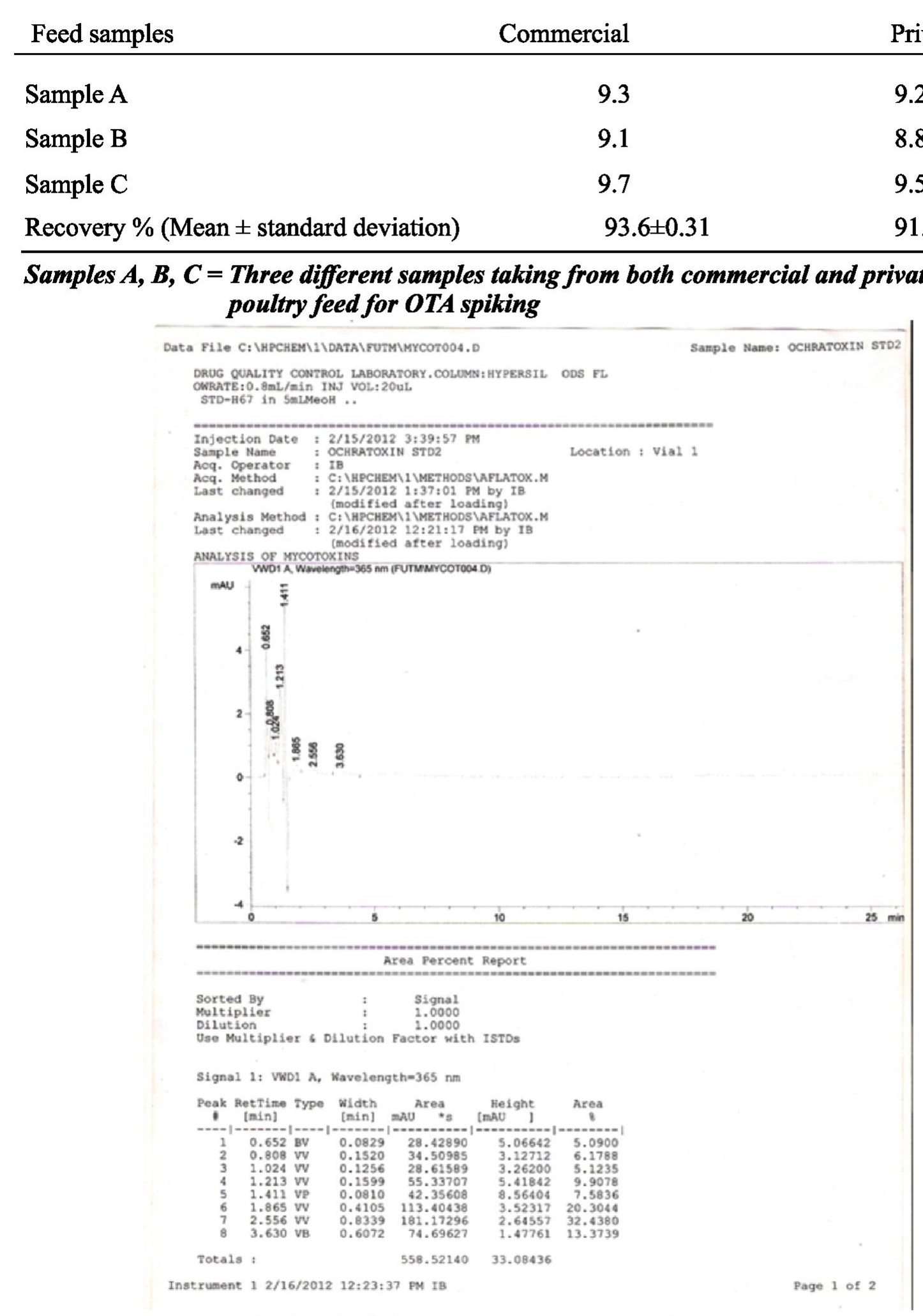

Figure 1 : Standard chromatogram of ochratoxin A. 


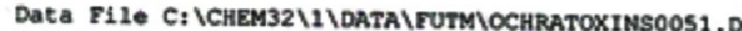

Sample Name: SPL A 28
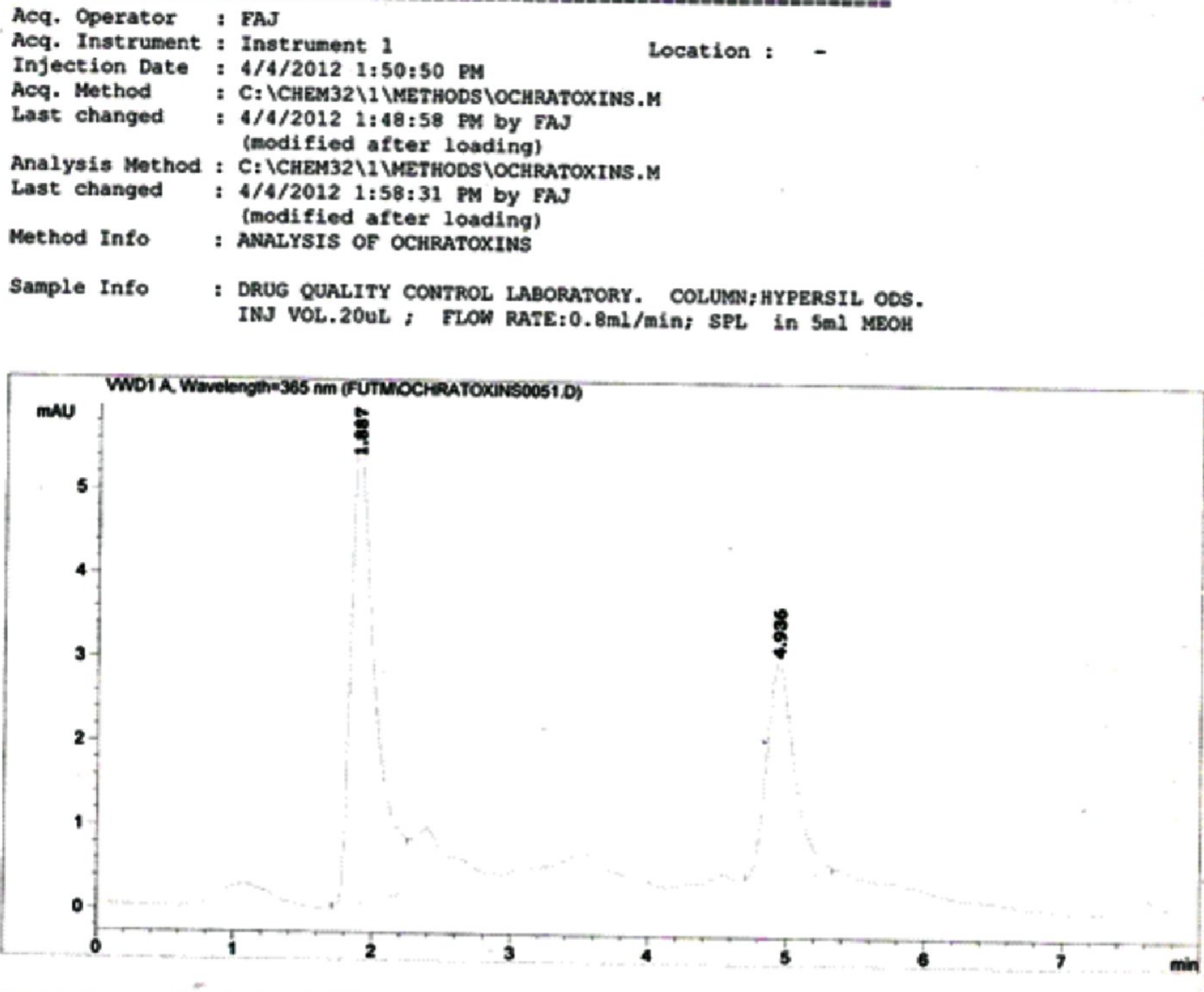

Area Percent Report

$\begin{array}{llcl}\text { Sorted By } & \text { signal } & \\ \text { Multiplier: } & & : & 1.0000 \\ \text { Dilution: } & & : & 1.0000\end{array}$

Use Multiplier a Dilution Factor with ISrDs

Signal 1: VWO1 A, Wavelength-365 nm

\begin{tabular}{|c|c|c|c|c|c|c|}
\hline Peak & RetTime & Type & width & Area & Height & rea \\
\hline 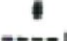 & [min] & & [min] & $m A d$ & ImAN $]$ & 8 \\
\hline $\begin{array}{l}1 \\
2\end{array}$ & $\begin{array}{l}1.887 \\
4.936\end{array}$ & $\begin{array}{l}\mathrm{BB} \\
\mathrm{BB}\end{array}$ & $\begin{array}{l}0.1801 \\
0.2076\end{array}$ & $\begin{array}{l}68.48345 \\
36.27612\end{array}$ & $\begin{array}{l}5.6156 \\
2.5589\end{array}$ & $\begin{array}{l}3720 \\
6280\end{array}$ \\
\hline
\end{tabular}

Instrument 1 4/4/2012 1:58:38 PM FAN

Figure 2: Chromatogram of OTA positive sample. 


\section{REFRENCES}

1. Shi, H., Li, S., Bai, Y., Prates, L.L., Lei, Y. and Yu, P. (2018). Mycotoxin contamination of food and feed in China: Occurrence, detection techniques, toxicological effects and advances in mitigation technologies. Food Control 91, 202-215. https://doi.org/10.1016/j.foodcont.201 $\underline{8.03 .036}$

2. Granados-Chinchilla, F., Molina, A., Chavarría, G., Alfaro-Cascante, M., Bogantes-Ledezma, D. and MurilloWilliams, A. (2017). Aflatoxins occurrence through the food chain in Costa Rica: Applying the One Health approach to mycotoxin surveillance. Food Control 82, 217-226. https://doi.org/10.1016/j.foodcont.201 7.06.023

3. Hussein, H.S. and Brasel, J.M. (2001). Toxicity, metabolism and impact of mycotoxins on humans and 348 animals. Toxicology. 167, 101-134

4. Stoev, S.D. (2017). Balkan Endemic Nephropathy - Still continuing enigma, risk assessment and underestimated hazard of joint mycotoxin exposure of animals or humans. Chemical Biology Interaction. 261, 63-79. https://doi.org/10.1016/j.cbi.2016.11.0 $\underline{18}$

5. Abarca, M.L., Accensi, F., Bragulat, M.R. and Cabanes, F.J. (2001). Current importance of Ochratoxin A producing Aspergillus spp. Journal of .Food Product. 64,903-906.

6. IARC, (1993). IARC Monographs on the Evaluation of Carcinogenic Risks to Humans: Some Naturally Occurring
Substances, Food Items and Constituents, Heterocyclic Aromatic Amines and Mycotoxins, Ochratoxin A, vol. 56, International Agency for Research Cancer, Geneva, 26-32.

7. Jorgensen, K., Rasmussen, G. and Thorup, L. (1998). Ochratoxin A in Danish cereals 1986-1992 and daily intake by the Danish population. Food Additive and Contaminant, 13,95-104.

8. Makun, H.A., Gbodi, T.A., Akanya, HO., Salako, E.A. and Ogbadu, G.A. (2009). Fungi and Some Mycotoxins fofound in Mouldy Sorghum in Niger State Nigeria. World Journal of Agricultural Sciences, 5(1), 5-17.

9. Ifeji, E. I. and Makun, H.A. (2012). Fungi and some Mycotoxin found in groundnuts (Arachis hypogea) from Niger State. MTech thesis submitted to Department of Biochemistry, Federal University of Technology, Minna, Nigeria. Pp 1-94.

10. Adeniran, L. A., Makun, H,A. and Mohammad, H.L. (2013). Mycobiota and the concentration of Ochratoxin A in poultry feed in Minna Nigeria, MTech thesis submitted to Department of Biochemistry, Federal University of Technology, Minna, Nigeria. Pg 1-94.

11. Elegbede, J.A., West, C.E. and Audu, A.A. (1982). Fungal and mycotoxin contamination of sorghum during storage in Northern Nigeria. Microbiology Letter, 19, 1982, 77-83

12. Gbodi, T.A., 1986. Studies of mycoflora and mycotoxins in acha, maize and cotton seed in Plateau State, Nigeria. A 
Ph.D thesis, submitted to Department of Physiology and Pharmacology, Faculty of Veterinary Medicine, ABU, Zaria, pg 1-213.

13. Adebajo, L.O., Idowu, A.A. and Adesanya, O.O.(1994). Mycoflora, and mycotoxins production in Nigerian corn and corn-based snacks. Mycopathologia. 126(3), 183-92

14. Okoli, C., Nweke, C.U., Okoli. G.C. and Opara, M.N. (2006). Assessment of the microflora of commercial poultry feeds fold in the humid tropical environment or Imo state,Nigeria. International Journal of Environmental Science and Technology, 3(1), 9-14

15. Ezekiel, C.N., Bandyopadhyay, R., Sulyok, M., Warth, B. and Krska, R. (2012). Fungal and bacterial metabolites in commercial poultry feed from Nigeria. Food Additive and Contaminant, PartA. 28, 1288-1299.

16. Ehrlich, K.C. and Lee, L. (1984). Mycotoxins in Grain Dust: Method for Analysis of Aflatoxins, Ochratoxin A, Zearalenone, Vomitoxin and secalonic acid. Journal of Association for Analytical Chemistry, 67 (5), 963-967

17. Engstrom, G.C., Richard, J.L. and Cysewski, S.J. (1977). High Pressure Liquid Chromatographic method for detection and resolution of rubratoxin, aflatoxin and other mycotoxins. Journal of Agriculture and Food Chemistry, 25, 1977, 833-836.

18. Beg, M.U., Al-Mutairi, M., Beg, K.R., Al-Mazeedi, H.M., Ali, L.N. and Saeed, T. (2006). Mycotoxins in poultry feed in Kuwait. Archive of Environmental
Contaminant and Toxicology. 50, 594-602.

19. Figueroa, S., Centeno, S., Calvo, M.A., Rengel, A. and Adelantado, C. (2009). Mycobiodata \& concentration of ochratoxin A in concentrated poultry feed from Venezuela. Pakistan Journal of Biological Sciences, 12, 589-594.

20. Jaimez, J. and Fente, C.A., Franco, M., Cepeda, A., Vazquez, A. (2004). A survey of the fungal contamination and presence of ochratoxin $A$ and zearalenone on Spanish feed and raw materials. Journal of Science, Food and Agriculture, 84, 832-840.

21. Makun, H.A., Gbodi, T.A. and Akanya, H.O., Salako, E.A., Ogbadu, H.A. (2007). Fungi and Some Mycotoxins contaminating rice (Oryza sativa) in Niger state, Nigeria. African Journal of Biotechnology, 6(2), 99-108.

22. Dimic, D., Nesick, $K$. and Pertovic, $M$. (2009). Mycotoxin in feed for pigs and poultry, Biotechnology and Animal husbandary, 25(6), 2009, 1149-1154.

23. Shareif, M. (2009). Molds and mycotoxins in poultry feeds from farms of potential mycotoxises. Iraq Journal of Veterinary Science, 24(1), 17-25.

24. Bozzo, G., Bonerba, E., Ceci, E., Colao, V. and Tantillo, G. (2011). Determination of ochratoxin $\mathrm{A}$ in eggs and target tissues of experimentally drugged hens using HPLC-FLD, Food Chemistry 126, 1278-1282. 
25. Rao, M. (2010). Influence of low levels of ochratoxin A on egg production, eggshell stains, and serum uric-acid levels in kghomtype hens. Avian Diseases, 24, 777-780.

26. Kozaczynski, W. (1994). Experimental ochratoxicosis in chickens. Histopathological and histochemical study. Archive of Veterinary Pathology, 34, 205-219.

27. Huff, W.E. and Ruff, M.D. (1982). Eimeria acervulina \& Eimeria tenella infections in ochratoxin A.compromised broiler chickens. Poultry Science, 61, 685-692.

28. Hamilton, R.M.G., Thompson, B.K. and Trenholm, H.L. (1986). The effects of deoxynivalenol (vomitoxin) on dietary preference of White Leghorn hens. Poultry Science, 65, 288-293.

29. Gupta, S., Jindal, N., Khokhar, R.S., Gupta, A.K., Ledoux, A.R. and Rottinghaus, G.E. (2005). Effect of ochratoxin A on broiler chicks challenged with Salmonella gallinarium Journal of Poultry Science, 46, 443-450.

30. Stoev, S.D., Koynarsky, V. and Mantle, P.G. (2002). Clinicomorphological studies in chicksfed ochratoxin A while simultaneously developing coccidiosis. Veterinary Research Communication, 26, 189-204.
31. CEC., (2006). (Commission of the European Communities), Commission Regulation (EC) No. 1881/2006 of 19 December 2006 setting maximum levels for certain contaminants in foodstuffs. O.J.E.U L-2006, 364, 5-24.

32. Duarte, S.C., Pena, A. and Lino, C.M. (2010). A review on Ochratoxin A occurrence and effects of processing of cereal and cereal derived food products. Food Microbiology, 27, 187198.

33. Wagacha, JM. and Muthomi, J. W. (2008). Mycotoxin problem in Africa: current status, implication to food safety and health and possible management strategies. International Journal of Food Microbiology, 124, 2008, 1-12.

34. Hult, K., Piestina, R., Habazin-Novak, V., Radic, B. and Ceovic, S. (1982). Ochratoxin A in human blood and Balkan endemic nephropathy. Archive of Toxicology, 51, 313. 